\title{
The Information Technology Outsourcing Advantage: India vs. China
}

Mohamad Sepehri, Jacksonville University, USA

Russell Baker, Jacksonville University, USA

Michael Adams, Jacksonville University, USA

\begin{abstract}
This study evaluates India and China as destinations for Information Technology (IT) outsourcing on five main parameters: workforce, capital investment, infrastructure, governmental policies, and the economy. While India would appear to have an edge in workforce and the economy, due primarily to its huge English speaking and software trained population and a more sustainable economic growth; China leads in investment and infrastructure as it offers much better financial incentives to companies. Based on our overall assessment of these five factors it, is concluded that India at present appears to be a better destination for IT outsourcing.
\end{abstract}

\section{INTRODUCTION}

lobalization is one of the most hotly debated topics in businesses throughout the world. One major component of globalization is the outsourcing of Information Technology jobs to lower cost countries like China and India. There appear to be several factors that contribute to a company's decision to outsource, albeit the primary motivation for outsourcing most often is cost reduction. Most companies who outsource find that outsourcing frequently adds value through increased productivity and quality improvements in addition to providing cost effective solutions. Today, approximately $80 \%$ of a company's IT budget is earmarked for maintenance and improving current software (Selip, 2006). This leaves companies with little money left-over to develop new software that will take the organization to the next level. Company CEOs are always looking for ways to reduce expenses and outsource their company's non-core competencies. The important question is where to outsource. China and India are the two obvious choices, but how can they be differentiated? This study attempts to answer this question by examining and evaluating the following selected critical areas to determine which country would give companies a competitive advantage in outsourcing: workforce, capital investment, infrastructure, governmental policies, and economy.

\section{Workforce:}

China and India are currently the major outsourcing providers to the US, largely due to the available low cost pool of qualified labor resources. Both countries have populations exceeding 1 billion, half of which are between the ages of 18 and 64 years of age (Aon, August 2005). The demographics that comprise the labor pools in China and India are important to the continued economic growth and prosperity of each country. Both China and India have built their economies' strength by emphasizing their outsourcing services potential. Each country has a specific competitive advantage in the outsourcing industry. China is viewed as a manufacturing outsourcing center, while India's primary focus is on information technology outsourcing projects (Frost \& Sullivan, June 2005).

In 2004, the IT world-wide outsourcing market was approximately $\$ 39.6$ billion, with India's share of the outsourcing market valued at approximately $\$ 17.2$ billion compared to China's $\$ 1.9$ billion. This translates into India capturing $43 \%$ market share compared to China's $5 \%$ market share. Table 1 clearly illustrates the dominance that India has over all other countries in global IT outsourcing. (Frost \& Sullivan, June 2005). 
Table 1: The IT Outsourcing Dominance of India vs. the world

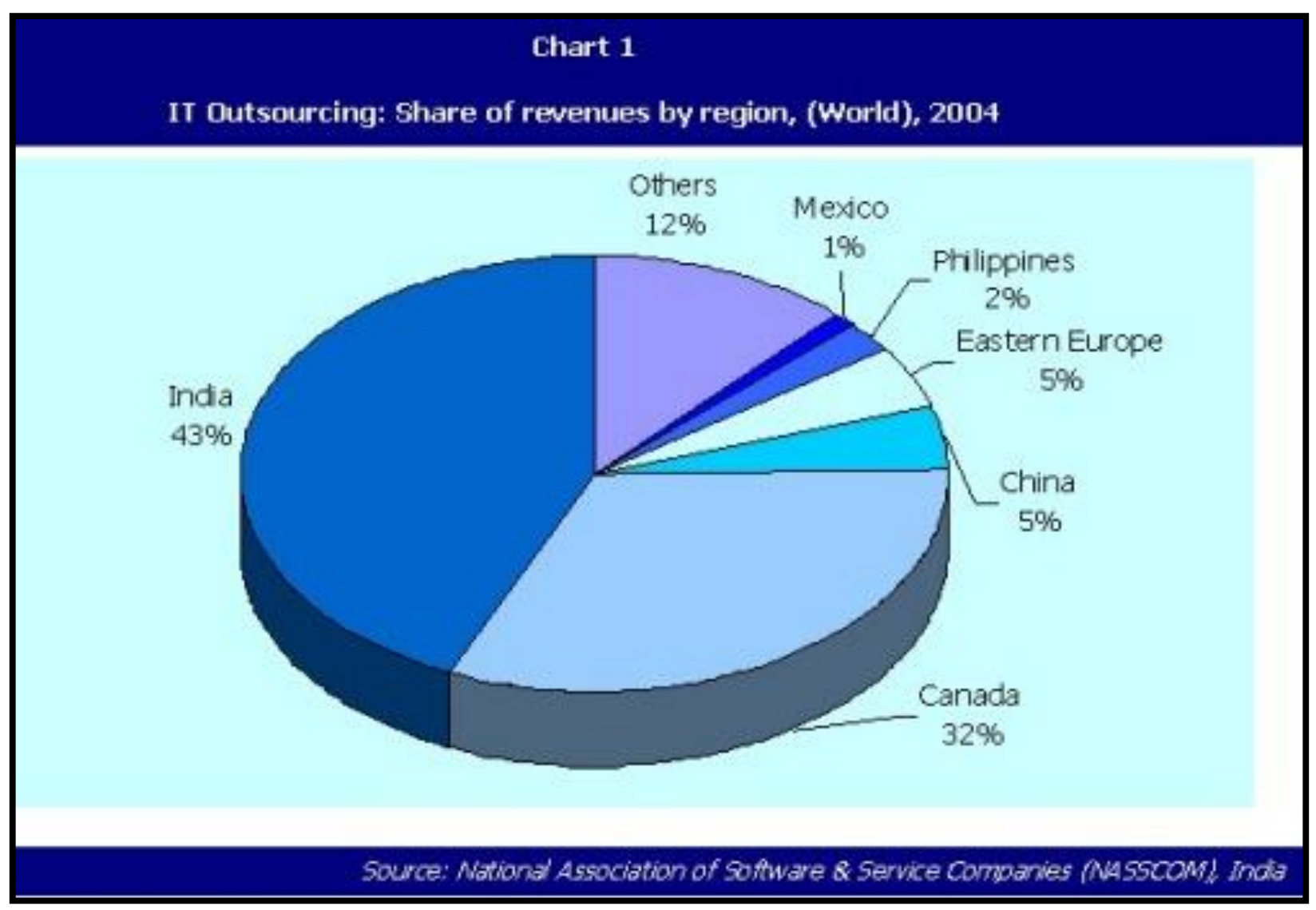

Frost and Sullivan (2005) have identified seven key success factors (KSF) for an information technology outsourcing provider country:

- $\quad$ Abundance of technically skillful labor

- $\quad$ Low cost workforce

- $\quad$ Quality of service

- Regulatory environment

- $\quad$ Robustness of infrastructure

- $\quad$ Knowledge of English

- Time zone attractiveness

Among these factors, skilled labor, low-cost workforce, and English speaking ability, account for more than $42 \%$ of the favorable rating total given the quality and quantity of the domestic workforce.

India has a significant advantage in these key factors. India has approximately 813,000 knowledge workers working in IT software and services organizations during 2003 and 2004. India universities supply the industry labor pool with approximately 3 million graduates annually, including 400,000 engineers (The New York Times, February 2006). The Indian workforce is skilled, low-cost and the workers speak English fluently. Approximately 1.2 million domestic workers are employed in the Indian IT outsourcing industry. Outsourcing in India constitutes approximately 5\% of the country's gross domestic product (GDP). Moreover, India is well versed in western business laws and practices. For this reason, corporations have focused on India as the outsourcing location for their Information Technology support function such as: customer service, writing software code, and designing chips 
(The New York Times, February 2006). India is by far the primary IT destination for US companies that outsource in the global market.

As of 2005, the offshore information technology and business process outsourcing industries of India currently employ over 695,000 people (McKinsey Global Institute, 2005). This number is expected to dramatically increase to approximately 1.5 million in the near future. "The IT sector is likely to be the key demand driver in the next decade by occupying 20 million square feet of commercial space each year" (CIRE Magazine, June 2006).

Table 2: Outsourcing Activities: India VS. Other Countries

\begin{tabular}{|c|c|c|c|}
\hline \multicolumn{4}{|c|}{$\begin{array}{l}\text { Expanding Beyond IT } \\
\text { Where does your company offshore or intend to offshore the following activities? }\end{array}$} \\
\hline ACTIVITY & $\begin{array}{l}\text { DEYEL OPED } \\
\text { COUNTRIES }\end{array}$ & $\begin{array}{c}\text { DTHER LOW-WAGE } \\
\text { COUNTRIES }\end{array}$ & INOIA \\
\hline Information technology & $5 \%$ & $27 \%$ & $65 \%$ \\
\hline Call center, help desk & $6 \%$ & $38 \%$ & $55 \%$ \\
\hline Business research analytics & $22 \%$ & $36 \%$ & $42 \%$ \\
\hline Finance, administration & $20 \%$ & $36 \%$ & $43 \%$ \\
\hline Human resources & $12 \%$ & $39 \%$ & $44 \%$ \\
\hline Industry-specific R\&D & $30 \%$ & $45 \%$ & $24 \%$ \\
\hline \multicolumn{4}{|c|}{ Figures do not equal 100 peroent due to founding of numbers } \\
\hline
\end{tabular}

China possesses similar advantages to India in outsourcing capability. Low cost abundant labor have made China an attractive alternative to India for US companies seeking foreign outsourcing partners. Significant disadvantages for China include poor English language abilities and limited understanding of western laws and business practices (Frost \& Sullivan, June 2005). The proficiency in English language is much more problematic in China than in India, but it has not necessarily impacted the ability of companies to work there (SBPOA, November 2004). In a survey of outsourcing buyers and suppliers, China was rated to be the third-best country for growth opportunities (after the U.S. and India). However, the two greatest challenges facing China continue to be the language and communication problems.

Albeit, most Chinese students study English in school, they have little or no proficiency in the spoken English language (SBPOA, November 2004). According to China Eventus Co Ltd (2005), China will have a large supply of educated English speaking resources in the long run. China has an increasing number of science and engineering doctoral graduates (Freeman, August 2005). It is estimated China will emerge as the major provider of overseas software outsourcing between 2007 and 2010 (Cyber Future, June 2006). China's labor-cost advantage over India is the driving factor for this trend. China's excess of qualified engineers will work for lower salaries than their Indian counterparts. An average monthly salary for a Chinese engineer is less than $\$ 500$, compared to over $\$ 700$ in India and $\$ 5,000$ or more in the U.S. (Cyber Future June 2006). Interest in China as an outsourcing destination has continuously increased in recent years, as wages in India has kept increasing. Ironically, the advantages that India has over China in business education and fluency in the English language are seen as the reasons the Indians are demanding greater compensation. 
Many multinational companies have started to adopt an "India-plus-China" approach to outsourcing. It is a common practice that US companies who are exploring the opportunities to establish a base in China now frequently ask their Indian outsourcing partners to assist them in securing such bases for them (Outsourcing Essentials, Spring 2004). India still has more experience with the scale and deliverability of projects, as well as more talent and management capability than China. The main reason cited for this is the language barrier; China must first improve their English proficiency standards and China must develop project management expertise to achieve economies of scale in order to complete on the global IT outsourcing stage.

Today, many Indian companies are establishing Chinese operations at an increasing rate. "Nearly 18 Indian companies have had operations in China and had a workforce of nearly 2000, with investments estimated to be nearly $\$ 50$ million. By the end of 2005, Indian companies are expected to expand their Chinese operations as well as double their employee base in China" (Frost \& Sullivan, June 2005). Many experts are calling this the new era of "Chindia" (Sondergaard, 2007). For example, IBM Corporation has recently decided that India and China are essential to the future success of the company and is globalizing its 200,000 workforce in each country based on available skill lines. The company is coordinating operations that are better and more economical. For example, the people supply chain is being revamped and human resources are being utilized in the areas that will add to the outsourcing company's bottom line.

The table below details the staffing for IBM in both India and China, and the work that will be performed in each of these countries. IBM plans to increase its total workforce in India by $377 \%$ and $71.5 \%$ in China (Business Week, June 2006).

Table 3 - IBM Corporation IT Global Services Staffing, BRIC Countries

Business Week, June 5, 2006.

\begin{tabular}{|c|c|c|c|}
\hline Location & $\begin{array}{c}2003 \\
\text { Staffing }\end{array}$ & $\begin{array}{l}\text { Current } \\
\text { Staffing }\end{array}$ & Work Performed \\
\hline India & 9,000 & $\begin{array}{l}43,000 \\
\text { (377\% increase) }\end{array}$ & $\begin{array}{ll}\checkmark & \text { Data centers } \\
\checkmark & \text { Software development } \\
\checkmark & \text { Call centers } \\
\checkmark & \text { Research }\end{array}$ \\
\hline China & 4,200 & $\begin{array}{l}7,200 \\
\text { (71.5\% increase) }\end{array}$ & $\begin{array}{ll}\checkmark & \text { Software development } \\
\checkmark & \text { Data centers } \\
\checkmark & \text { Demonstration center } \\
\checkmark & \text { Research } \\
\end{array}$ \\
\hline Brazil & 4,500 & $\begin{array}{l}9,000 \\
(\mathbf{1 0 0 \%} \text { increase })\end{array}$ & $\begin{array}{ll}\checkmark & \text { Data centers } \\
\checkmark & \text { Linux development lab } \\
\checkmark & \text { Call centers }\end{array}$ \\
\hline $\begin{array}{l}\text { Eastern Europe } \\
\quad \text { (Russia) }\end{array}$ & 2,900 & $\begin{array}{l}5,125 \\
\text { (75\% increase) }\end{array}$ & $\begin{array}{ll}\checkmark & \text { Data centers } \\
\checkmark & \text { Service skill centers } \\
\checkmark & \text { Linux development labs }\end{array}$ \\
\hline
\end{tabular}

\section{Capital Investment:}

Each country has followed a completely different approach to capital investment. The Indian government has taken proactive steps by developing industrial parks with the necessary infrastructure and internet backbone required for an IT company to be successful. The Indian government requires new companies to build out the remaining infrastructure such as office spaces and provides no incentives for training new employees. However in China, the Chinese government has taken a less "hands-on" directed approach with regards to the development of 
the necessary infrastructure requirements (Clyde Prestowitz, 2005). The Chinese government offers financial aid packages for each new plant being built. Companies can build in pre-arranged areas in China and be exempt from taxes for 20 years. The land will be provided free of charge and import duties will be exempted. The Chinese government also provides grants to help train the workforce. They will also give grants that cover half of the capital investment for companies signing long-term deals (Prestowitz, 2005). Currently, India does not match these types of incentives; however, companies must remember that India has an established IT network, and the Chinese government is trying to make inroads into the IT segment. This is an important competitive advantage for India.

In India, only three possibilities exist for a US company to gain direct access to the Indian workforce. Two of the three options available to foreign companies involve selecting and partnering with Indian firms to gain access to local knowledge and expertise in local regulations. The third option for a company to setup outsourcing operations is to go through the regulatory process alone where administrative red tape can cause delays in getting the project started. The two popular choices for entry in India will be Assisted Build, Transfer, and Operate (ABTO), where the company will hire local consultants to handle the local subcontracting and the second, to facilitate any dealings with the government. The process is broken down by two choices on which to operate. The first is the BTO option (Build, Transfer, and Operate). This option requires the Indian company to build the structures, and then transfers equity ownership directly to the company. The second option is Build, Operate, and Transfer (BOT). The Indian partners will build, start initial operation, and transfer to the parent company at a designated time. These two options also have the backing of the Indian government since they require local Indian companies to have part ownership in the process (Davies, 2004). The current process in India to acquire an operating license takes approximately 270 days at a cost of $\$ 4,206$ (Doingbusiness.org, 2006). The process can be expedited by having an Indian partner apply for the license since most of the firms in India have contacts in the government that can expedite paperwork. By following this route unnecessary waiting time and delays can be minimized.

In China, the government is more open and has reduced a lot of administrative red tape. For example, in 1988, Motorola CEO Robert Galvin, wanted to open a plant in China after he saw China's desire to become an economic force. Galvin met with the Chinese leadership and persuaded them to change the restriction of joint ventures and other bureaucratic conditions that the government levied on new companies entering the Chinese market (Prestowitz, 2005). China loosened the red tape and allowed foreign ownership of land. This allowed new companies such as Motorola to acquire the land and then turn around and lease it back to a Chinese company to use for outsourcing operations. This allowed more foreign capital investment into China. However one of the bureaucratic barriers that were not decreased was the amount of time for a company to get a license to operate. It takes approximately 363 days for approval to operate a company at an average cost of $\$ 1,527$ (Doingbusiness.org, 2006). The barriers to entry are meant to insure that both countries have their own citizens involved in the process to protect their national interest. The cost factor for both are relatively low compared to most developed nations. The Chinese are more aggressive in relaxation of barriers than Indians, however, this can also be attributed to the fact the China is not yet a dominant player in the IT outsourcing marketplace.

\section{Infrastructure:}

Adequate telecom facilities are a critical factor that is paramount for the success of the software and IT outsourcing service industry. China has invested heavily in modernizing its physical infrastructure of buildings and manufacturing facilities while India has invested more heavily in their communications infrastructure. The telecommunications revolution has greatly benefited India by enabling easy export of digitized information. India's growth and development in the telecom, power, and transportation resources has also helped shape their remarkable IT success (IndoBase, 2006). The typical IT infrastructure criteria that companies use for selecting an offshore site include: telecommunications, technologically advanced firms, data security, and facilities and transportation.

India has an excellent telecommunication infrastructure; Internet Service Provider and cellular services are available in IT outsourcing Indian host cities. Bandwidth for international data communication has significantly expanded over the past 3 years. Moreover, the telecom privatization initiative in India has resulted in both significant rate drops (costs have dropped approximately $85 \%$ over the last 3 years) while simultaneously improving service. Power infrastructure improvements have resulted in continuous electricity availability to IT destination 
cities like Bangalore, Delhi, Chennai, Bombay, Pune, and Calcutta. Indian state governments have reformed the power sector to improve power supply infrastructure to IT service companies.

Stable satellite and submarine telecommunication links enable excellent connectivity between India and the rest of the world enabling seamless IT outsourcing communication. Furthermore, Indian IT companies provide state of the art software applications in: E-commerce, business process re-engineering, system migration, maintaining legacy systems, and system integration which further contribute to India's IT outsourcing success.

While the physical infrastructure in India is not as well developed as it is in China, India has recently made major improvements to roads and highways. India now has many major multi-lane highways, interconnecting all the principal outsourcing cities. This is critical to the continued success of IT outsourcing in India. China has a better physical infrastructure than India; spending considerably more on developing that infrastructure. However, China has not yet made significant inroads into the IT global outsourcing market. The primary reasons for this include a lack of IT infrastructure, poor English skills, and cultural incompatibility. China's government is taking steps to improve the infrastructure by creating technology parks in many areas of country. The English language skills problem is being addressed by making English a compulsory language in schools. These steps are intended to enhance China's status as the premier IT outsourcing destination. The national economic policy and the growth in IT structure network are more aggressive in China than in India, which would facilitate further growth in telecommunication and networking capabilities (CIO Insight, October 2005).

\section{Government Policies:}

India has a stable democratic government and is one of the world's fastest-growing economies. Capital markets in India are more efficient and transparent than in China. Moreover, India's legal system is decidedly more pro-business and less restrictive than China's. The potential of IT to influence future economic development is well understood by the Indian government. IT is now one of the top priorities of the Indian government and favorable policies are being formulated to extract maximum benefits from the industry. In recent years, the Indian government has introduced new policies (i.e. reducing the licensing requirements; promoting FDI and investments; transparent and investment-friendly policies; IT Act 2000; venture capital funding; NASSCOM) to help fuel the economic engine for further growth in the IT industry (World Bank, 2006).

The table below shows the growth in IT production of India. Much of the credit for the growth is given to favorable governmental policies that stimulate more and more outsourcing to India.

Table 4: Indian Production in the IT Industry, The World Bank (2006)

\begin{tabular}{|lrrrrr|}
\multicolumn{1}{l}{} & & & \multicolumn{2}{c}{ (Rs. crore) } \\
\hline \multicolumn{1}{|c}{ Item } & $\mathbf{1 9 9 7 - 9 8}$ & $\mathbf{1 9 9 8 - 9 9}$ & $\mathbf{1 9 9 9 - 2 0 0 0}$ & $\mathbf{2 0 0 0 - 0 1}$ & $\mathbf{2 0 0 1 - 0 2}$ \\
\hline IT Hardware & 22,100 & 25,250 & 28,100 & 30,700 & 32,750 \\
Software Exports & 6,500 & 10,940 & 17,150 & 28,350 & 36,500 \\
Domestic Software & 3,470 & 4,950 & 7,200 & 9,400 & 11,634 \\
Total & 32,070 & 41,140 & 52,450 & 68,450 & 80,884 \\
\hline
\end{tabular}

IT service providers in China are working in conjunction with the government to compete in the global IT outsourcing market. India's 44.0 percent market share of IT outsourcing significantly leads China's market share, however, the gap is expected to decrease when China begins leveraging their advantages (Frost, June 2005).

Although China is an attractive outsourcing destination, it still lags behind India in a number of key success factors. The Chinese government is, however, initiating efforts to enhance China's position as an offshore hub in providing outsourced IT services. China is making great strides to improve the qualified workforce available for outsourcing through government initiatives. For example, starting 100 new technological higher education institutions and making English compulsory in schools to increase the number of English speaking people. 
To counter the competitive moves from India and to stimulate the growth in IT industry, the Chinese government has implemented several key IT policies (Outsourcing Institute, 2006). These key policies include: zero duty, standards development on core IT technologies, Intellectual Property Rights (IPR) protection, outbound M\&A activities, and expanding the IT talent pool. Although India currently is the dominate player with $43 \%$ of the aggregate market in IT outsourcing, China is aggressively gearing up with favorable policies to encourage companies to bring the work to China. Government efforts to enhance the future of IT outsourcing in China are succeeding as several large multinationals have expanded operations in the Chinese market.

\section{Economy:}

In determining which country is best suited for information technology outsourcing, the economies of both countries must be evaluated. Healthy and steady growth in an economy is one of the key areas that potential businesses look at when choosing an outsourcing country. However, with any economy, there is a certain amount of the risk. Companies must weigh this risk in order to choose which country is best suited for them. After all, no company will outsource to a country that has a risky economy with little growth or potential for growth. Chinese and Indian economic development is a major factor affecting which country is best for information technology outsourcing.

Table 5: Growth rate of GDP in India.

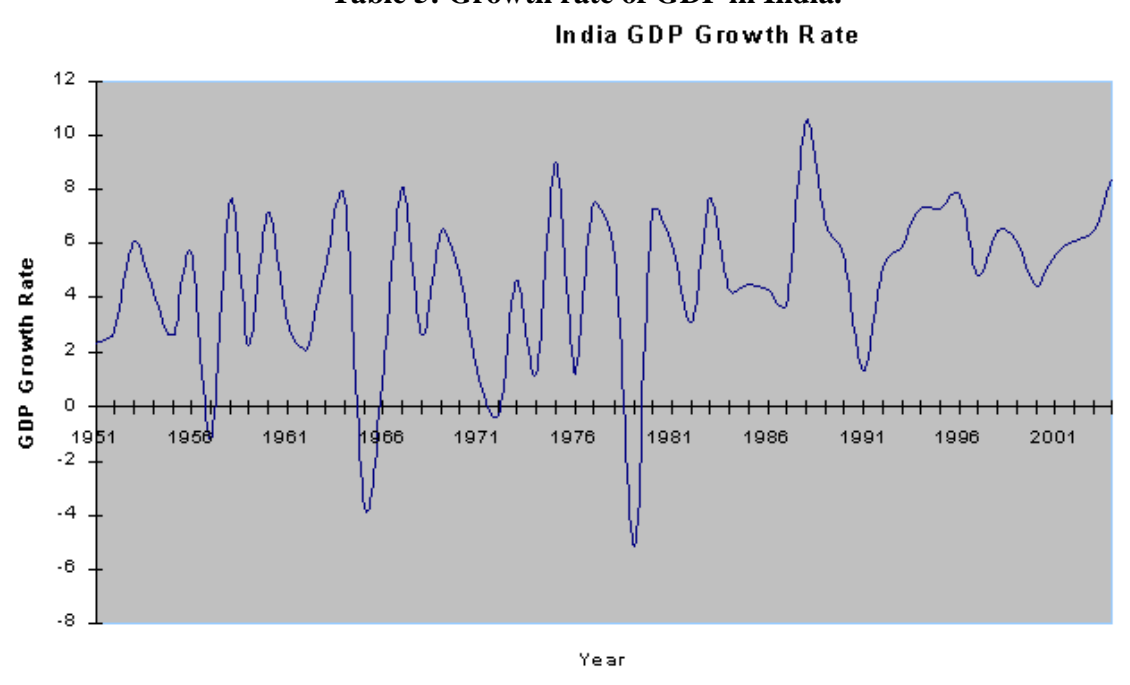

The government of India has made several official public statements concerning the direction of the economy and their "vision" for 2020 (Davies 2004). In order to accomplish this vision, India acknowledges that they must first eradicate poverty. They also realize that they have a daunting program ahead of them in doing so, but the Indian government has stated that they are steadfastly single-minded in their goal. India believes that they will succeed and help change the global economy. As indicated in Table 5 below, the current economic growth in India is readily apparent and substantial. India's GDP growth of 4.9 percent, industrial production growth of 5.9 percent, and consumer inflation of less than 6 percent,, rank India's overall economic growth third world wide (Davies 2004). India's GDP has increased consistently since 1999.

India's share of world wide GDP is expected to "rise from 6 per cent to 11 per cent in 2025 and hence, the latter (India) will emerge in third place in terms of size in the global economy after the US and China" (Economy Watch). India's economy should approximate 60 percent of the size of the United States economy by 2025. The transformation into a fully functioning global economy is envisioned to be complete by 2035 when India's economy is anticipated to be only slightly smaller than the United States and larger than Western Europe. "By 2035, India is likely to be a larger growth driver than the six largest countries in the EU, though its impact will be a little over half that of the US" (Davies 2004). 
Table 6: Growth rate of the GDP of China.

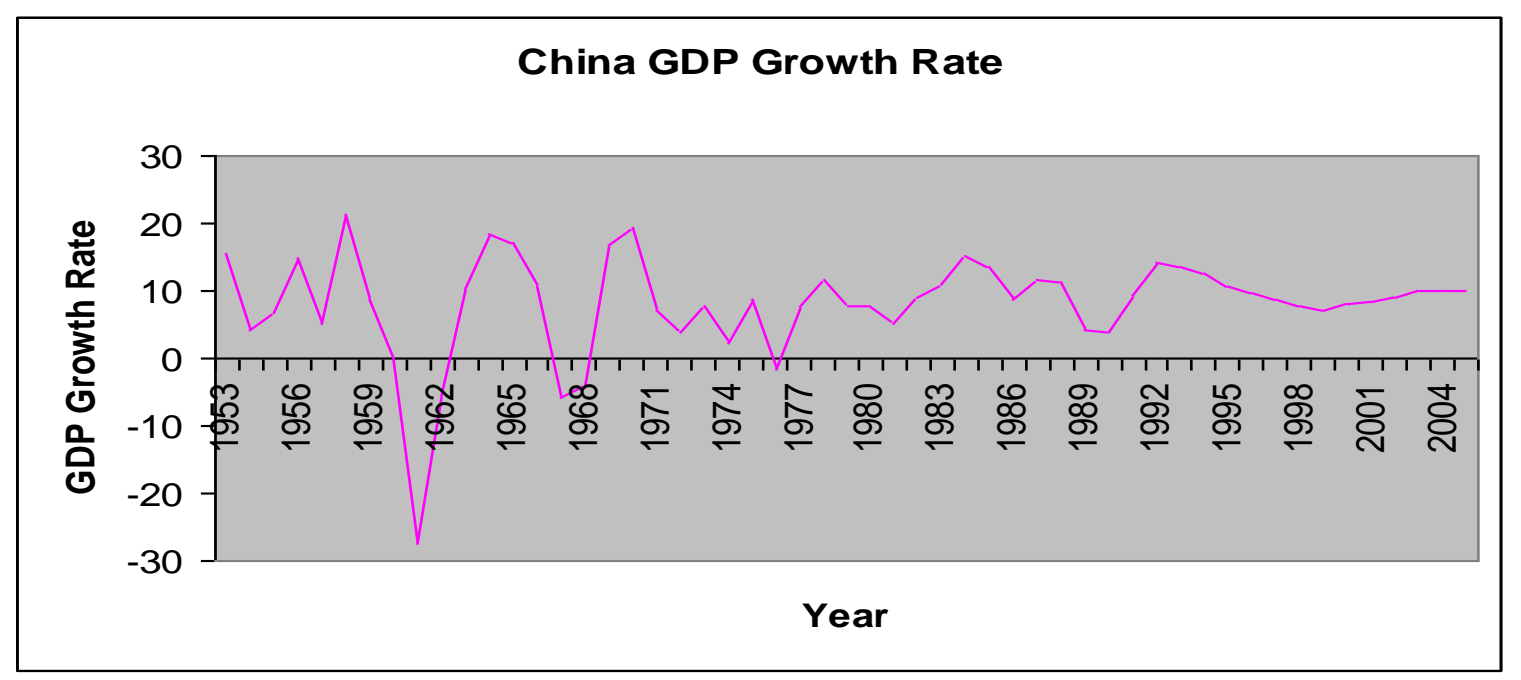

China is currently "the fastest-growing economy in the world" (Economy Watch). Table 6 shows that China's current estimated growth rates for GDP range from about 6.7 percent to 16.5 percent (Davies 2004). Compared to India, the data shows that the gap in GDP growth is only about 1.8 percent, with much wider gap of 10.8 percent in the industrial production growth rate. However, India has much higher growth in services revenues than China (Chinability.com, 2006). If the present economic growth rate continues, China is expected to quadruple its GDP by year 2020 (China Daily, 2005). Unlike some concerns about China's Economic growth (Jubak, 2007), the Chinese government is confident that "China's economy is capable of maintaining an annual growth rate of 8 to 9 per- cent over the next 5 to 10 years" (China Daily, 2005).

During the period 1993 to 2002, the high-tech industry's contribution to overall national output doubled from less than 10 percent to more than 20 percent (China Daily, 2005). It is not much surprising that some believe that China's GDP could overtake the U.S. sometime in the next 50 years. India's GDP is expected to grow at half the rate of growth in China's GDP during the same time period (International Economy, 2006). Given these staggering statistics, China appears to have a clear advantage when it comes to estimated future economic growth.

With each business venture, there is risk. Economic risk is no different. The economic risk associated with India is evident. The "Left Front" has stalled labor reform, impeded privatization, and limited foreign investment. However, the current Indian federal budget is likely to jeopardize the current growth prospects. In current terms, for instance, the oil price shocks of $\$ 100$ a barrel oil could negatively impact India as one of the largest oil importers. Weather could also affect the economy. Just like hurricanes in Florida, monsoons in India could damage the economy. However, there does not appear to be as much risk in the economy as one would think (Economist Intelligence Unit, 2006). The government and the Reserve Bank of India have focused on inflation and they are determined to make sure that it stays in check.

Many experts agree that the economy in China is growing too rapidly (Jubak, 2006). The question, however, is will it just slow down, or will it crash? Just like in India, oil prices could adversely affect the Chinese economy as they are a major oil importer. The boom in China has been led by capital investment, which means demand has dramatically increased as well as supply. However, overinvestment could cause a decrease in profitability, swell bank's non-performing loans, or even bankrupt some firms. With the large overinvestment, communist Chinese banks, mostly owned by the government, increase their inefficiency with loans especially with "bad debts" which may account for up to 50 percent of total loans made (The Economist, 2005). This usually results in higher interest rates due to stricter requirements for borrowing. A hard economic landing would also increase domestic unemployment that would breed social unrest. China acknowledges these problems and has responded by instituting reform, but when the government controls half the economy, the risk ultimately lies solely with the 
Chinese government. There is little doubt China will not be able to sustain such high growth forever. This does not mean businesses should write off the economy of China; however it does mean that US companies should exercise caution in all the firm's outsourcing endeavors. Nevertheless, it appears India has less exposure to economic risk factors than China, and the consequences of a potential economic downturn are less severe.

\section{CONCLUSIONS}

Both India and China have staked out their positions and goals to capture a greater share of the global IT outsourcing marketplace. Both countries seek to be the dominate player in the global market for IT outsourcing. However, there can only be one dominant outsourcing country, and it appears that the country is currently, and will continue to be, India. India holds several strategic advantages. While India and China are both low-cost alternatives, India holds a clear edge in both technical education of workforce and English language speaking abilities. Both countries do not face any shortages of people in the available workforce; however, India has more specialized IT workers with better English skills than their Chinese counterparts.

China's advantages include more tax incentives, free land use, and they will even help train the workforce tailored to the particular needs of their outsourcing clients. China also leads in societal infrastructure like highways, thoroughfares, and structures; while India has a better IT infrastructure with respect to networks and internet access. There appears to be a draw when it comes to governmental relations. Both countries desire to capture a larger share of the IT outsourcing market.

Although both countries' economies are rapidly expanding, China's economy is growing at a higher accelerated rate. Associated with this accelerated growth rate are greater potential risks. Any global economic downturn could spell disaster for China, given the Chinese economy is overextended. India's economy is very steady and should experience a consistently high growth rate for the foreseeable future. While both countries have a plan going forward to increase their advantages and to decrease their deficiencies, at present, it is better to outsource to India for IT work than in China. This is not to say China will not catch up to India in the next 25 years, but for now and the foreseeable future, India will be the IT outsourcing premier country of choice.

Table 7: Summary table of key success factors by country

\begin{tabular}{|c|c|}
\hline \multicolumn{2}{|c|}{ India } \\
\hline Advantages & Disadvantages \\
\hline $\begin{array}{l}\text { Abundance of technically skilled labor } \\
\text { Time zone attractiveness } \\
\text { English fluency } \\
\text { Low cost workforce } \\
\text { Quality of service } \\
\text { Telecommunication infrastructure }\end{array}$ & $\begin{array}{l}\text { Regulatory environment } \\
\text { Physical Infrastructure }\end{array}$ \\
\hline \multicolumn{2}{|l|}{ 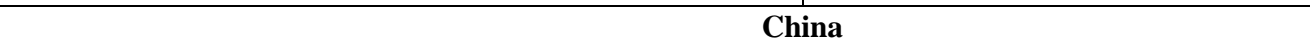 } \\
\hline $\begin{array}{rc}\text { Advantages } \\
\end{array}$ & $\begin{array}{r}\text { Disadvantages } \\
\end{array}$ \\
\hline $\begin{array}{l}\text { Physical infrastructure } \\
\text { Low cost workforce } \\
\text { Regulatory environment }\end{array}$ & $\begin{array}{l}\text { Lack of English speaking } \\
\text { Time zone limitations } \\
\text { Quality of service } \\
\text { Lacking technically skilled labor pool } \\
\text { Telecommunication infrastructure }\end{array}$ \\
\hline
\end{tabular}

\section{REFERENCES}

1. AON Focus. (2005, August 15). India and China: The keys to global business factors. Retrieved June 24, 2006, from http://www.aon.com/about/publications/focus/focus_2005_aug_15.jsp.

2. Bremmer, Ian. (2006, March 7). China's Underpopulation Crisis - India has one, too. Slate. Retrieved June 23, 2006, from http://www.slate.com/id/2137680/. 
3. Briody, Dan. (2005, October). China Aims to Outpace India in IT Outsourcing. Retrieved June 23, 2006, from http://www.cioinsight.com/article2/0,1540,1867061,00.asp.

4. BusinessWeek Magazine. (2006, June 5). Big Blue Shift.

5. Chen, Savio. (2006, April). How China's Five Emerging Drivers Are Changing the Technology Landscape and IT Industry. Retrieved June20, 2006, from http://www.outsourcing.com/china_trends/pdf/IT_Outsourcing_China.pdf.

6. China's Economy: Time to Hit the Brakes. (2005, May 13). The Economist, May13, 2006. Retrieved June 24, 2006, from http://www.economist.com/opinion/displaystory.cfm?story_id=2668182.

7. CIRE Magazine. (2006, June 23). India Calls. Retrieved from http://www. ciremagazine.com/article.php?artical id=894\&format=print.

8. $\quad$ Cyber Future. (2006, June 17). China Outsourcing. Retrieved June 17, 2006, from http://www.cyfuture.com/china-outsourcing.htm.

9. Dashen, X. (2005, March 21). China's economy to grow 8\% annually from 2006 to 2010 . Retrieved June 24, 2006, from http://www.chinadaily.com.cn/english/doc/2005-03/21/content 426718.htm.

10. Davies, P. (2004). What's This India Business?: Offshoring, Outsourcing, and the Global Services Revolution. London: Nicholas Brealey International.

11. Doingbusiness.org. (2006). Explore Economies-China. Retrieved June 23, 2006, from http://www.dointbusiness.org/exploreeconomies/defaultaspx?economyid42.

12. Doingbusiness.org. (2006). Explore Economies-India. Retrieved June 23, 2006, from http://www.dointbusiness.org/exploreeconomies/defaultaspx?economyid89.

13. Freeman, Richard. (2005, August 30). China, India and the Doubling of the Global Labor Force: who pays the price of globalization? ZNet Activism. Retrieved June 23, 2006, from http://www.zmag.org/content/print_article.cfm?itemID=8617\&sectionID=1.

14. Frost \& Sullivan. (2005, June 8). IT Outsourcing: China versus India. Retrieved June 17, 2006, from http://www.frost.com/prod/servlet/cif-econ-insight.pag?docid=39745707.

15. GDP growth 1952-2006. (2006, May 21). Retrieved June 24, 2006, from http://www.chinability.com/GDP.htm.

16. India: Country Outlook. (2006, May 19). The Economist Intelligence Unit ViewsWire. Retrieved June 24, 2006, from ProQuest Database.

17. Indian Economy Overview. Retrieved June 24, 2006, from http://www.economywatch.com/indianeconomy/indian-economy-overview.html.

18. Infrastructure. (2006, January). Retrieved June 23, 2006, from http://www.indobase.com/bpo/whyindia/infrastructure.html.

19. Jubak, Jim, China's Economy is Out of Control, Jubak's Journal, MSN Money, July 2006.

20. The New York Times. (2006, February 16). India's Outsourcing Industry Facing a Labor Shortage. Retrieved June 23, 2006, from http://www.nytimes.com/2006//02/16/business/worldbusiness/16cndINDIA.html?ei=508.

21. Outsourcing Essentials. (2004) Vol 2, No 1. Look out India, China is gaining on you. Retrieved June 23, 2006, from http://www.outsourcing.com/content.asp?page= 01b/other/oe/q104/india 2. html\&nonav=t...

22. Prestowitz, C. (2005). Three Billion New Capitalist: The great shift of wealth and power to the east $\left(I^{\text {st }}\right)$. New York: Basic Books.

23. SBPOA. (2004, November 30). Serviced in China: The next wave of outsourcing? Retrieved June 17, 2006, from http://www.sharedservicesbpo.com/file/2257/ serviced-in-china-the-next-wave-of-outsource...

24. Selip, S. (2006, February 21). Software Development Outsourcing and Offshoring Risks And Rewards. Burton Group.

25. Sondergaard (2007), Do you have a Chindia Strategy?, Forbes, Retrieved October, 2007 from www.forbes.com.

26. Wolf, Martin. (2006, February). Will India Grow Faster than China. Retrieved June 20, 2006, from http://economistsview.typepad.com/economistsview/2006/02/will india grow.html.

27. World Bank Institute (2006, May). The Rise of China and India and its Implications for the Global. Retrieved June 24, 2006, from http://siteresources.worldbank.org/INDIAEXTN/Resources/e - 2006-05-31.

28. Wu, F. (2006). Will India Steal China's Thunder? The International Economy, Spring 2006. Retrieved June 24, 2006, from http://www.international-economy.com/TIE_SP06_IndiaChina.pdf. 